\title{
'What gets measured gets managed': revisiting the indicators for maternal and newborn health programmes
}

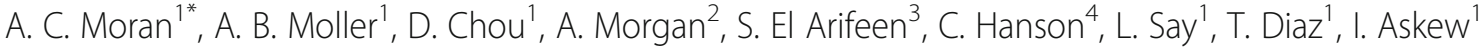 \\ and A. Costello ${ }^{1}$
}

\begin{abstract}
Background: The health of women and children are critical for global development. The Sustainable Development Goals (SDG) agenda and the Global Strategy for Women's, Children's, and Adolescent's Health 2016-2030 aim to reduce maternal and newborn deaths, disability, and enhancement of well-being. However, information and data on measuring countries' progress are limited given the variety of methodological challenges of measuring care around the time of birth, when most maternal and neonatal deaths and morbidities occur.

Main body: In 2015, the World Health Organization launched Mother and Newborn Information for Tracking Outcomes and Results (MoNITOR), a technical advisory group to WHO. MoNITOR comprises 14 independent global experts from a variety of disciplines selected in a competitive process for their technical expertise and regional representation. MoNITOR will provide technical guidance to WHO to ensure harmonized guidance, messages, and tools so that countries can collect useful data to track progress toward achieving the Sustainable Development Goals.

Short conclusion: Ultimately, MoNITOR will provide technical guidance to WHO to ensure harmonized guidance, messages, and tools so that countries can collect useful data to track progress toward achieving the Sustainable Development Goals.
\end{abstract}

Keywords: Maternal, Newborn, Measurement, Monitoring

\section{Background}

The health of women and children are critical for global development. The Sustainable Development Goals (SDG) agenda [1] and the Global Strategy for Women's, Children's, and Adolescent's Health 2016-2030 aim to reduce maternal and newborn deaths, disability, and enhancement of well-being [2]. However, information and data on measuring countries' progress are limited given the variety of methodological challenges of measuring care around the time of birth, when most maternal and neonatal deaths and morbidities occur. National and global monitoring efforts focus on coverage of antenatal care, skilled attendance during birth and postnatal care, however the content and quality of care during these interactions are largely unmeasured and unreported [3-5].

\footnotetext{
* Correspondence: morana@who.int

${ }^{1}$ World Health Organization, Geneva, Switzerland

Full list of author information is available at the end of the article
}

To fill this gap, several measurement groups are working on indicators and methodologies, providing often conflicting recommendations of what should be measured at global, national and sub-national levels. Their work advances the field, but they confuse countries on what and how to measure or to track progress toward ambitious SDG targets. Although SDG core indicators are agreed, an operational framework and core set of common indicators for all countries is not yet established.

\section{Main text}

The Millennium Development Goals final report stated that "data are an indispensable element of the development agenda" [6]. Other health areas have profited from coordinated measurement initiatives. The Malaria Monitoring and Evaluation Reference group and UNAIDS Monitoring and Evaluation Reference Group facilitate 
partner alignment, harmonize indicators, and communicate key measurement issues $[7,8]$.

In 2015, the World Health Organization launched Mother and Newborn Information for Tracking Outcomes and Results (MoNITOR), a technical advisory group to WHO. MoNITOR comprises 14 independent global experts from a variety of disciplines selected in a competitive process for their technical expertise and regional representation. The vision of MoNITOR is to facilitate measurement, align initiatives, and provide technical guidance to WHO. WHO leads by coordinating metrics related to maternal and newborn health.

MoNITOR held two meetings to review ongoing measurement efforts, map maternal and newborn indicators and data sources, and assess gaps. Three cochairs, technical experts from Australia, Bangladesh and Sweden, advise MoNITOR's work. Emerging issues include a lack of consistent definitions for key indicators across varying data collection platforms. Over the next 2 years, MoNITOR will provide recommendations for priority indicators, norms and standards for data collection platforms, a coordinated research agenda, and how to build regional capacity. WHO is also building a simpler, real-time, integrated database for maternal and newborn indicators included in the Global Strategy.

\section{Conclusion}

Ultimately, MoNITOR will provide technical guidance to WHO to ensure harmonized guidance, messages, and tools so that countries can collect useful data to track progress toward achieving the Sustainable Development Goals. See http://www.who.int/maternal_child_adolescent/epidemiolo gy/monitor/en/ for additional information.

\section{Abbreviations \\ MoNITOR: Mother and Newborn Information for Tracking Outcomes and \\ Results; SDGs: Sustainable Development Goals}

\section{Acknowledgements}

Not applicable.

Funding

Support for the MoNITOR technical advisory group is provided by the Bill \& Melinda Gates Foundation.

\section{Availability of data and materials}

Not applicable.

\section{Authors' contributions}

$A C M$ and $A B M$ drafted the original manuscript. All authors reviewed, provided feedback, and approved the final manuscript.

\section{Ethics approval and consent to participate}

Not applicable.

\section{Consent for publication}

Not applicable.

\section{Competing interests}

The authors declare that they have no competing interests.

\section{Publisher's Note}

Springer Nature remains neutral with regard to jurisdictional claims in published maps and institutional affiliations.

\section{Author details}

${ }^{1}$ World Health Organization, Geneva, Switzerland. ${ }^{2}$ University of Melbourne, Melbourne, Australia. ${ }^{3}$ ICDDR, B, Dhaka, Bangladesh. ${ }^{4}$ Karolinska Institutet,

Stockholm, Sweden.

Received: 14 December 2017 Accepted: 23 January 2018

Published online: 02 February 2018

References

1. Sustainable development goals. http://www.un.org/sustainabledevelopment/ sustainable-development-goals/. Accessed 26 Jan 2018.

2. Every Woman, Every Child. The global strategy for Women's, Children's, and Adolescent's health (2016-2030). Geneva: World Health Organization. http:/ www.who.int/life-course/partners/global-strategy/globalstrategyreport20162030-lowres.pdf. Accessed 1 Sept 2017.

3. Marchant T, Bryce J, Victora C, Moran AC, Claeson M, Requejo J, et al. Improved measurement for mothers, newborns and children in the era of the sustainable development goals. Journal of Global Health. 2016;6(1)

4. Grove J, Claeson M, Bryce J, Amouzou A, Boerma T, Waiswa P, et al. Maternal, newborn, and child health and the sustainable development goals - a call for sustain and improved measurement. Lancet. 2015; https:/doi.org/10.1016/ S0140-6736(15)00517-6.

5. Hodgins S, D'Agostino A. The quality-coverage gap in antenatal care: toward better measurement of effective coverage. Glob Health Sci Pract. 2014; https://doi.org/10.9745/GHSP-D-13-00176.

6. United Nations. The millennium development goals report 2015. New York: New York. 2017. http://www.un.org/millenniumgoals/2015_MDG_Report/ pdf/MDG\%202015\%20rev\%20(July\%201).pdf. Accessed 25 Sept 2017.

7. Roll Back Malaria. https://rollbackmalaria.com/organizational-structure/ working-groups/merg/. Accessed 26 Jan 2018.

8. UNAIDS. http://aidsmerg.org/about-us/. Accessed 1 Sept 2017.
Submit your next manuscript to BioMed Central and we will help you at every step:

- We accept pre-submission inquiries

- Our selector tool helps you to find the most relevant journal

- We provide round the clock customer support

- Convenient online submission

- Thorough peer review

- Inclusion in PubMed and all major indexing services

- Maximum visibility for your research

Submit your manuscript at www.biomedcentral.com/submit
Biomed Central 